\title{
Indian deep sea fisheries - its prospects, issues and challenges
}

\begin{abstract}
Fisheries play a pivotal role in the economic development of all maritime nations. The fisheries sector contributes as foreign exchange earner, ensures nutritional security and generates employment opportunities. With absolute rights on the EEZ, India has also acquired the responsibility to conserve, develop and optimally exploit the marine resources up to 200 nautical miles off our coastline. ${ }^{1}$ The current exploitation from the marine capture sector is 3.44 million tonnes in 2013-14 as against the potential of 4.41 million tonnes. Indian marine fish harvest mostly centers around coastal waters up to 100 meters depth and about 90 per cent of the catch comes from up to $50 \mathrm{~m}$. A recent revalidation of marine fisheries potential has shown that the fishing pressure on the stock in near shore waters has gone up considerably and signs of over exploitation of species is becoming increasingly evident and further increase in effort in the coastal sector would be detrimental to sustainable yield. In case of India, the total production for Yellowfin tuna has fluctuated from 7544 tonnes in 2011 to 22, 155 tonnes in 2008. However, in case of Skipjack tuna, production has declined from 18934 in 2011 to 7212 tonnes in 2012. In other words, India is presently harvesting about $12 \%$ of the potential and the balance can be optimally harvested using a judicious mix of technology, infrastructure and human resource development. As the coastal fishery faces issues like the sustainability, resources conservation and management; there is an imperative need for finding an alternative resource for the nutritional security. Exploitation of under exploited non-conventional resources from the distant waters of the Indian EEZ will be the only solution. There is ample scope of increasing production by venturing into deeper waters of the EEZ, which holds a potential of 1.7 million tonnes of underexploited and unexploited fin fishes and shellfishes. This indicates there is an ample scope for development of this sector. In this context, the aim of the present study was to analyse scenario of marine fisheries in India with respect to potential and discuss in detail the Deep-sea fishing, its Prospects, Issues and Challenges in India.
\end{abstract}

Volume 5 Issue 2 - 2017

\author{
Pratysh Das, ${ }^{2}$ Sinha MK,' Anrose A,' Babu \\ $C^{\prime}$ \\ 'Fishery survey of India, Fishing harbour complex, India \\ ${ }^{2}$ Fishery survey of India, Phoenix Bay, Andaman and Nicobar \\ Islands
}

Correspondence: Pratysh Das, Fishery survey of India, Phoenix Bay, Portblair, Andaman and Nicobar Islands, Tel +9l 9679534088,Email pratyush84@gmail.com

Received: December 31, 2016 | Published: January 31, 2017

\section{Introduction}

According to Food and Agriculture Organization (FAO), Deepsea fisheries are those that take place at great depths and many deepsea fisheries take place in waters beyond national jurisdiction (such as the Exclusive Economic Zone [EEZ]), that is in the high seas. In recent years, the deep sea fishery resources have become the iconic last frontier for the expansion and in forefront of marine fisheries. In general, marine living resources caught in the high seas always pose scientific and technical challenges. Worldwide a number of governmental and non-governmental organizations with mandates relating to conservation of the environment, biodiversity and management of fisheries have expressed concerns about the likely, known or feared consequences of deep-sea fishing in terms of its effects and impacts on target stocks, associated species and habitats. ${ }^{2}$

The above said concerns were reflected in resolutions adopted by the United Nations General Assembly and led to the adoption of specific recommendations by the FAO Committee on Fisheries at its twenty-seventh session, in March 2007, which prompted the subsequent development and adoption (in August 2008) of the FAO International Guidelines for the Management of Deep-sea Fisheries in the High Seas. ${ }^{2}$

Fisheries play a pivotal role in the economic development of all maritime nations. The fisheries sector contributes as foreign exchange earner, ensures nutritional security and generates employment opportunities. Among the total world fish production India contributes more than 4 per cent. Even though the country unable to reach the annual per capita fish consumption of $11 \mathrm{~kg} / \mathrm{yr}$, the present per capita consumption is around $9 \mathrm{~kg}$, it shows the need for an immediate additional nutritional requirement of the country. ${ }^{3}$ India is the largest country in the Indian Ocean region comprising a coastline of 8129 $\mathrm{km}$. With absolute rights on the EEZ, India has also acquired the responsibility to conserve, develop and optimally exploit the marine resources up to 200 nautical miles off our coastline (Planning Commission, 2007). The current exploitation from the marine capture sector is 3.44 million tonnes in $2013-14$ as against the total projected potential of 4.41 million tonnes.

Indian marine fish harvest mostly centers around coastal waters up to 100 meters depth and about 90 per cent of the catch comes from up to $50 \mathrm{~m}$. A recent revalidation of marine fisheries potential has shown that the fishing pressure on the stock in near shore waters has gone up considerably and signs of over exploitation of species is becoming increasingly evident and further increase in effort in the coastal sector would be detrimental to sustainable yield. The impact of undeterred mechanized trawling andpurse seining has also caused resource depletion. Sustainable resources exploitation from this sector is still possible through regulatory management strategies and concerted policy efforts for different species and for different regions. ${ }^{4}$

Technological lag and financial constraints had been the major bottlenecks in the delayed take off of the deep-sea fishing industry in India. The maritime states of Gujarat, Kerala and Tamil Nadu have already demonstrated their ability to harvest deep-sea fisheries resources in the Indian EEZ using vessels below $20 \mathrm{~m}$. Nevertheless the major contribution in fish production still continues to be from coastal waters. ${ }^{5}$ 
Anrose et al. ${ }^{6}$ (Where in I am one of the author) presented in the IOTC working party meeting (WPTT13) that the contribution of the deep sea fisheries are mainly the larger pelagics like tuna and allied species. The production in general shows marked fluctuation in the last 30 years. Exploration and exploitation of the fishery resources in this area over the past 3 decades have shown that the oceanic tuna resources in this area consists of the Yellowfin tuna (Thunnus albacares) the Bigeye tuna (Thunnus obesus) and the Skipjack tuna (Kastuwonus. pelamis). The Indian EEZ is about $2.8 \%$ of the surface area of the Indian Ocean $\left(73,556,000 \mathrm{~km}^{2}\right)$ with nine maritime states and four union territories including Andaman \& Nicobar group of Islands and Lakshadweep Islands. The fishery in India is confined to shallow inshore waters. In Lakshadweep island, the Skipjack Tuna and small fraction of juvenile Yellowfin tuna which enters the surface waters are caught by pole and line and troll lines.

As per the report of Anrose et al. ${ }^{6}$ though the proximity of our country to the resources facilitates profitable exploitation of the fishery, the pace of development is rather unsatisfactory even after the enactment of the Law of the Sea (1976) and subsequent withdrawal of the foreign fleet from the sea. During September, 1960 to February, 1965 M.V. Pratap belongs to Fishery Survey of India (erstwhile deep sea fishing station and off shore fishing station) conducted six cruises of long lining in the Arabian sea. Later an indigenous trawler converted long liner M.V. Meena Prayas continued long lining during 1972. Though the results were encouraging, the programme would not be continued in the right perspective for want of adequate vessels and lack of infrastructure facilities. However FSI acquired two long liners from Japan under the Japanese aid programme during 1981 for training in tuna longlining and for survey of tuna resources, the activities gained considerable momentum. Matsya Sugandhi, the $31.5 \mathrm{~m}$ Japanese built long liner based at Cochin base of Fishery Survey of India (1980-1988) has enormously expanded the area of investigation achieving spectacular results with respect to the landings of Yellowfin tuna.

Subsequently the service undertaken by another Norwegian aided vessel, Matsya Harini (1980-1988) built in Goa Shipyard also made valuable contribution to enhance our information and viability of tuna fishing. Since these vessels had significant results within limited area, the Government of India under India-Japan co operation brought two Japanese built tuna long line vessels M.V. Yellow Fin and M.V. Blue Marlin during the year 1989. With the acquisition of these two vessels, the FSI could commence an organized and systematic survey of the tunas in the Indian EEZ. The vessel M.V.Yellowfin is deployed for survey along the North West coast of India while M.V. Blue Marlin is carrying our survey around Andaman and Nicobar Island. ${ }^{6}$

During 1989-90, a study was conducted where in Vijayakumaran et al. ${ }^{7}$ stated that fourteen charter vessels ( $36 \mathrm{~m}$ multifilament tuna long liners) operated 2000 hooks/day in the Indian EEZ and the estimated average catch per voyage ( 30 days/Voyage) was 28.78 tonnes. Which consists of $69.26 \%$ Yellowfin tuna, $0.85 \%$ Bigeye tuna ,0.11\%, Skipjack tuna 6.5\% Bill fishes ,23.28\% Sharks and other fishes. Later in the year 2005 the tuna long line surveys were carried out using multifilament long line gears.

More recently, FSI with the objective of introducing and popularizing the monofilament long ling technology in the Indian waters had acquired two monofilament long liners namely Matsya Vrushti and Matsya Drushti during February, 2005 which are deployed for survey in Arabian sea along the West coast and in Bay of Bengal and Andaman Nicobar Waters along the East coast, within the Indian EEZ respectively.
Detailed accounts on the distribution of tuna resources in Indian ocean have been given by Suda (1974) ,Suzuki (1979), Sivasubramaniyan (1981), Silas and Pillai (1982) ${ }^{9}$ Silas (1983), Dwivedi and Devaraj (1983). ${ }^{8-10}$ The tuna fisheries in the Indian Ocean have observed that resources availability is never a constraint in its development. ${ }^{11-14}$ Siva Subramanian et al. ${ }^{14}$ has discussed the tuna fisheries in the EEZ of India, Maldives and Sri Lanka while Eapen ${ }^{15}$ and Joseph ${ }^{11}$ have given some aspects of developmental prospects of tuna fishing in Indian waters on the basis of exploratory survey conducted during the sixties. Varghese et al. ${ }^{16}$ given the detail results obtained from the survey conducted during April 1983 to March 1984. Sulochanan et al. ${ }^{17} 1986$, made a preliminary observation on the tuna resources with particular reference to Yellow fin tuna in the Arabian Sea for the period October 1983 to December 1985. He highlighted the impressive hooking rate suggesting high commercial viability of tuna longlining. Based on the survey results carried out the Matsya Sugandhi, Sivaprakasam \& Patil ${ }^{18}$ gave an account of the data on distribution and abundance of tuna and tuna like fishes of South -West coast of Indian during the period May 1985 to March 1986. Distribution and abundance of oceanic fishery resources of Andaman and Nicobar waters was presented by Anrose et al. ${ }^{19}$ The changes in the exploration and exploitation of oceanic tuna resources in the Indian EEZ from 1970's was made by Anrose et al. ${ }^{6}$ by analysing the results of Fishery Survey of India survey along the Indian EEZ which is a comprehensive study made till date. The paper highlights the history and status on tuna long line fishery in Indian EEZ till 2012.

Presently tuna fisheries are the one of the important fisheries in India. The Fishery Survey of India (FSI) being the premier institute of Govt. of India has carried out exploratory resource surveys around Indian waters including Andaman and Nicobar Islands (A\&N Islands) deploying various tuna long-liners since 1983 to understand the dynamics of these resources. Earlier studies based on the exploratory survey data provided the information on occurrence, spatial distribution and abundance of oceanic tuna resources around Arabian sea, Bay of Bengal and A\&N Islands Sudarsan et al., ${ }^{20-24}$ Anrose et al. ${ }^{6,18}$ In this context, the aim of the present study was to analyze the scenario of marine fisheries in India with respect to potential and discuss in detail the Deep-sea fishing, its Prospects, Issues and Challenges in India.

\section{Prospects}

Deep sea fishery over the years has undergone several changes like modernisation of fishing practices along with diversification, intensification and extension of fishing to new grounds and landing from incidental by catch to targeted commercial fishery. In India the coastal fishery sector is now facing challenges like the sustainability, resources conservation and management; therefore, there is an urgent need for looking forward the unexploited or least exploited resources so as to meet demand towards the nutritional security of the country as a whole. At this juncture, exploitation of under exploited nonconventional resources from the distant waters of the Indian EEZ is the only solution left with us. Moreover, there is an ample scope for increasing production by venturing into deeper waters of the EEZ, which holds a potential of 1.7 million tonnes of underexploited and unexploited fin fishes and shellfishes (ICAR,2011). ${ }^{25}$ This indicates the amount of opportunity available with us for development of this sector is huge.

\section{Fisheries potential}

Pursuant to the declaration of the Indian EEZ in 1976, estimation of potential yield became a necessary condition for sustainable management of fisheries. The United Nations Convention on Law 
of the Sea of 1982 (UNCLOS, 1982), which provides a validation for declaration of EEZ also came with the rider that while doing so (declaring EEZ), the coastal nations should ensure sustainability of the resources. Since India's ratification to the UNCLOS, 1982, various scientific studies have been carried out to estimate the fisheries potential in the marine waters of the country. In this regard the first attempt was made in 1980 and thereafter the potential is being regularly revalidated through decadal exercises, the latest being conducted during 2010. While these estimates are prima faciecomparable, there are also some changes from time to time. The 2010 Expert Committee tasked with the revalidation work noted that between the latest and the past potential estimates, there are some significant changes, such as increase in depth of fishing operations and fishing area and also likely impacts of climate change, especially on pelagic species. Following the 2010 revalidation, the potential yield from the Indian EEZ has

Table I Change in potential yield from the Indian EEZ

\begin{tabular}{llll}
\hline Realm & $\mathbf{2 0 1 0}$ & $\mathbf{2 0 0 0}$ & Change (\%) \\
\hline Pelagic & $21,28,424$ & $16,73,545$ & 27.18 \\
Demersal & $20,66,763$ & $20,17,071$ & 2.46 \\
Oceanic & $2,16,500$ & $2,43,800$ & -11.20 \\
Total & $44,11,687$ & $39,34,416$ & 12.13 \\
\hline
\end{tabular}

Table 2 Depth wise Potential yield in Indian EEZ and its share

\begin{tabular}{llll}
\hline Depth $(\mathbf{m})$ & Resource & PotentialYield (Tonnes) & Share (\%) \\
\hline $0-100$ & Demersal & $18,25,115$ & 41.37 \\
& Pelagic & $19,96,393$ & 45.25 \\
& Total & $38,21,508$ & 86.62 \\
$100-200$ & Demersal & $2,05,104$ & 4.65 \\
& Pelagic & 53,935 & 1.22 \\
& Total & $2,59,039$ & 5.87 \\
$200-500$ & Demersal & 98,205 & 2.23 \\
& Pelagic & 16,435 & 0.37 \\
$>500$ & Total & $1,14,640$ & 2.60 \\
$0-500+$ & Oceanic & $2,16,500$ & 4.91 \\
\hline
\end{tabular}

Table 3 Landing of Tuna and Tuna like Fishes from Indian Waters during 2008-20I2

\begin{tabular}{|c|c|c|c|c|c|c|c|}
\hline Species & 2008 & 2009 & 2010 & 2011 & 2012 & Total & AVE \\
\hline Yellowfin Tuna & 22155 & 11683 & 7968 & 7544 & 22045 & 71395 & 14279 \\
\hline Big Eye Tuna & 5229 & 5256 & 1428 & 1224 & 11334 & 24471 & 4894.2 \\
\hline Skipjack Tuna & 10176 & 10363 & 9565 & 18934 & 7212 & 56250 & 11250 \\
\hline Sword Fish & 1221 & 1287 & 3094 & 167 & 184 & 5953 & 1190.6 \\
\hline Sail Fish & 27 & 28 & 1883 & 34 & 33 & 2005 & 401 \\
\hline Marlin & 2832 & 2849 & 888 & 6322 & 1033 & I3924 & 2784.8 \\
\hline Long Tail Tuna & 22125 & 17153 & 12958 & 3909 & $1318 \mid$ & 69326 & 13865.2 \\
\hline Auxis Spp & 7135 & 8127 & 6695 & 10922 & $|804|$ & 50920 & 10184 \\
\hline Kawa Kawa & 3377 & 2346 & 3493 & 5849 & 3659 & 18724 & 3744.8 \\
\hline Tuna Like Fishes & 10053 & 14066 & 17900 & 86752 & 16288 & 145059 & 29011.8 \\
\hline Wahoo & 1420 & 0 & 2596 & 424 & 303 & 4743 & 948.6 \\
\hline Spanish Mackerel & 5512 & 5696 & 6235 & 52304 & 8517 & 78264 & 15652.8 \\
\hline King Mackerel & 48685 & 48705 & 47174 & 3209 & 59670 & 207443 & $4 \mid 488.6$ \\
\hline Scomberomerus Spp. & 44994 & 47511 & 42769 & 26835 & 44546 & 206655 & $4|33|$ \\
\hline Struooed Seer Fish & 8778 & 8812 & 12335 & 31905 & 6393 & 68223 & I3644.6 \\
\hline Total & 193719 & 183882 & |7698| & 256334 & 212439 & 1023355 & 20467 I \\
\hline
\end{tabular}

(Source: Hand Book on Fisheries Statistics, 2014; Govt. of India)

n revised upward to by 12 percent. The increase is largely due to a substantial increase of 27 percent in estimated potential yield of pelagic resources. On the other hand, there is a decline in the potential yield of oceanic resources by 11 percent (Table 1).

In the current estimates, the harvestable potential of marine fishery resources in the EEZ has been estimated at about 4.41 million tonnes (mt). An estimation of the depth-wise potential shows that about 87 percent of the resources $(3.82 \mathrm{mt})$ are available in $0-100$ meter depth; about 6 percent $(0.25 \mathrm{mt})$ in 100-200 meter depth zone and about 3 percent in 200-500 $(0.11 \mathrm{mt})$ meter depth zone. The resources in depths beyond 500 meter have been estimated at $0.216 \mathrm{mt}$, which is about 5 percent of the total resources (Table 2). The oceanic resources are largely composed of larger pelagic like tuna and tuna like species. But the deep sea demersal resources such as deep sea shrimps, deep sea lobsters, deep sea squids etc. potential are yet to be estimated. 
Table 4 State-wise detail of Existing fishing crafts in India (NMFC, 20I0)

\begin{tabular}{|c|c|c|c|c|c|}
\hline SI.No & State/Union Territory & Traditional & Motorized & Mechanized & Total \\
\hline I & Andhra Pradesh & 17837 & 10737 & 3167 & 31741 \\
\hline 2 & Goa & 227 & | 297 & I 142 & 2666 \\
\hline 3 & Gujarat & I 884 & 8238 & 18278 & 28400 \\
\hline 4 & Karnataka & 2862 & 7518 & 3643 & 14023 \\
\hline 5 & Kerala & 5884 & 11175 & 4722 & 21781 \\
\hline 6 & Maharashtra & 2783 & 1563 & 13016 & 17362 \\
\hline 7 & Odisha & 4656 & 3922 & 2248 & 10826 \\
\hline 8 & Tamil Nadu & 10436 & 24942 & 10692 & 46070 \\
\hline 9 & West Bengal & 3066 & -- & 14282 & 17348 \\
\hline 10 & Andaman \& Nicobar Islands & 1637 & | $49 \mid$ & 61 & 3189 \\
\hline 11 & Daman and Diu & 321 & 359 & 1000 & 1680 \\
\hline 12 & Lakshadweep & 727 & 606 & 129 & I 462 \\
\hline
\end{tabular}

Looking at the potential of both the Arabian sea and the Bay of Bengal, it is seen that the South-east Arabian Sea (SEAS) has a potential yield of about 1.70 million tonnes $(\mathrm{mt})$ comprising demersal fishery resources of about $0.42 \mathrm{mt}$ and pelagic fishery resources of about $1.28 \mathrm{mt}$; the North-east Arabian Sea (NEAS) has a potential of about $1.25 \mathrm{mt}$ comprising demersal fishery resources of about $0.21 \mathrm{mt}$ and pelagic fishery resources of about $1.04 \mathrm{mt}$; the Northern Bay of Bengal (NBOB) has a potential of about $0.61 \mathrm{mt}$ comprising demersal fishery resources of about $0.07 \mathrm{mt}$ and pelagic fishery resources of about $0.54 \mathrm{mt}$; the Southern Bay of Bengal (SBOB) has a potential of about $0.36 \mathrm{mt}$ comprising demersal fishery resources of about $0.12 \mathrm{mt}$ and pelagic fishery resources of about $0.24 \mathrm{mt}$ and the Andaman Seas has a potential of $0.40 \mathrm{mt}$ comprising demersal fishery resources of about $0.04 \mathrm{mt}$ and pelagic fishery resources of about $0.36 \mathrm{mt}$.

In terms of species-wise potential, perches (ribbonfish, threadfin breams, etc) and clupeids (oil sardine, etc) and crustaceans (shrimps, etc) comprise 47 percent of the resource potential. These resources are concentrated in waters up to 100 meters. Elasmobranches and tunas constitute about 12 percent of the potential and are the main oceanic resources.

\section{Major Deep sea resources and scope of their exploitation}

Based on the report of the 2010, Revalidation Committee, the total potential of oceanic waters is estimated at 216500 tonnes, including Yellowfin tuna (37\%) and Skipjack tuna (46\%). Other major species include Bigeye tuna, Billfishes, Sharks, Barracuda, Dolphin fish, Wahoo, etc., and comprise about 17 percent of the total. From the species composition it is clear that the primary objective of exploring oceanic fishery should be to exploit quality Yellowfin tuna resources and complement this with skipjack tuna and other resources such as Bigeye tuna and Billfishes.

India is still a small player in global tuna fisheries. Except the Lakshadweep group of Islands, there is hardly any organized tuna fishery in India. Synonymous with tuna fishing, the Lakshadweep Islands abound in skipjack followed by yellow fin. Fish aggregating devices such as 'payao' were introduced in Lakshadweep for increasing tuna catch and have performed well. Similarly, the Lakshadweep Administration is introducing larger fishing vessels (12 and 17 meters overall length) for increasing tuna catches from its waters. Baitfish fishing also forms an important component of the pole and line tuna fishing of Lakshadweep and could become a constraint in future if not managed sustainably. The Lakshadweep tuna largely goes for local consumption, canning at the canning plant located in Minicoy Island and for preparation of masmin, a delicacy in the Islands and in some parts of southern India. Small quantities of masminare also exported to Sri Lanka.

In the Bay of Bengal, the Andaman and Nicobar Islands offer some of the best tuna fishing grounds in the Indian EEZ. However, due to lack of capacity and weak forward and backward linkages prevailing in the Islands, tuna resources from the Andaman and Nicobar waters have largely remained unexploited. Since the oceanic tunas are migratory in nature, the tunas that could have been caught by the Indian fleet in the Andaman and Nicobar waters mostly get harvested in the EEZs of the neighbouring countries or in the high seas by the fleet of the distant water fishing nations.

Simultaneously, the small-scale fishing sector, especially off the coast of Visakhapatnam and in some coastal districts of southern Tamil Nadu has also ventured into tuna fishing. These initiatives include the targeting of Skipjack and Yellow fin tunas (particularly in Vishakapatnam) using troll line, hand line, gill nets and hook and line. In southern Tamil Nadu (Nagapattinam area), large floating devices are being developed to aggregate tuna and tuna-like species. Tuna fishing on the east coast is seasonal and takes place for about 7-8 months (August -March). Further, in Nagapattinam and other fishing centres located on Palk Bay, fishers are also seriously considering converting their trawlers into long liners and moving offshore for fishing tuna and tuna-like species.

In the indigenous expertise on offshore fishing for tuna and tunalike species, the Toothoor-based (in Kanyakumari district of Tamil Nadu) artisanal fishermen deserve particular mention. The Toothoor deep sea fishermen are not only fishing in different areas of the Indian EEZ (mostly in the Arabian sea), but also in Areas Beyond National Jurisdiction (ABNJ). Since 2006 onwards, MPEDA has also initiated conversion of trawlers into tuna long liners and most of such conversions have taken place in southern districts of Tamil Nadu.

In terms of potential of tuna fishery in the Indian Ocean, IOTC has estimated the maximum sustainable yield (MSY) for Yellowfin tuna at 344000 tonnes with a range between 290000 tonnes and 453000 tonnes. The IOTC has further advised (in 2012) that the annual catch of Yellowfin tuna should not exceed 300000 tonnes to ensure that stock biomass levels can sustain production at MSY level. Incidentally, the average catch from the India Ocean during 2008-12 is 317505 tonnes, which exceeds this limit. However, the stock is not overfished or subject to overfishing as per the 2013 estimates of IOTC.

In the case of Skipjack tuna, the MSY is estimated at 478190 tonnes and the average catch during 2008-12 has been estimated at 
400980 tonnes. Therefore, the stock is in good status and there is scope for further exploitation, albeit limited. In case of India, the total production for Yellowfin tuna has fluctuated from 7544 tonnes in 2011 to 22, 155 tonnes in 2008. However, in case of Skipjack tuna, production has declined from 18934 in 2011 to 7212 tonnes in 2012. In total, on an average, during 2008-12, India has exploited 25,259 tonnes of Yellowfin and Skipjack tuna from its waters against a potential of 179000 tonnes (80 000 tonnes Yellowfin tuna +99000 tonnes Skipjack tuna). In other words, India is presently harvesting about $12 \%$ of the potential and the balance can be optimally harvested using a judicious mix of technology, infrastructure and human resource development.

At current local market prices, these tuna resources alone (Yellowfin and Skip kack) are valued at 1394 crores or US D 232 million. If big eye, bill fishes and other tuna like resources are added, this value goes up to INR 1790 crores or about US D 300 million. It is also estimated that if proper post-harvest care is taken, the value of the Indian tuna resources can go up to US D 500 million. Therefore, a large amount of revenue is being lost every year due to under exploitation and or poor post-harvest care of the oceanic resources from the country's EEZ.

India has a fishable potential of 20800 tonnes of pelagic sharks in the oceanic waters. Shark fishery might seem to be lucrative in the short run, but it has a dubious long-term future in respect of trade, given the growing international campaign against shark fishery. From ecological perspectives also, unless it can be ensured that sharks caught are fully utilized and not just finned, it is not recommended to promote targeted shark fishery. Further to add that oceanic sharks are mostly large growing apex predators. They have low fecundities and stock replenishment takes time. They play a vital role in the food web and population balance. Many shark species have been over-harvested and conservation agencies such as the IUCN (International Union for Conservation of Nature), CITES (Convention on Trade in Endangered Species) and CMS (Convention on the Conservation of Migratory Species of Wild Animals) have been strongly voicing the need for full moratorium on shark fishing. Shark is also a major by-catch in tuna longlining and increase in fishing effort in tuna longlining will create additional pressure on shark stocks, unless the operators adhere to practices that minimize by-catch such as those of sharks. Therefore, any targeted shark fishery should be discouraged.

Apart from the above oceanic pelagic resources the non conventional deep sea resources available in our waters also provides ample scope for this sector. According to Hashim ${ }^{4}$ among these resources, the present commercial exploitation is limited only to deepsea shrimps like Metapenaeopsis andamanensis, Aristeus alcocki, Plesionika spinipes, Heterocarpus gibbossus and H. woodmasoniand deep-sea sharks mainly Echinorhinus brucusand Centrophorus spp. In his report he added that apart from this other non-conventional fishes like Neopinnula sp, Chlorophthalmus sp. were marketed for domestic consumption in Kerala and Tamilnadu. There exist huge amount of unutilized and underutilized resources like Psenopsis cyanea, Bembrops caudimacula, Chlorophthalmus bicornis, C. agassizi, Uranoscopus archionema, Gavialiceps taeniola, Priacanthus hamrurand Neoepinnula orientalisare revealed by the study based on the exploratory surveys conducted in Indian waters Hashim. ${ }^{4}$ Resources like Bulls Eye (Priacanthus spp.), Black ruff (Centrolophus niger), Chloropthalmus spp., Trichurus auriga, Neoepinula orientalis, Pseneopsis cyanea, Deep sea shrimps, deep sea lobsters and squids, myctophids etc. are also available which is still in vergin state. This indicates that this resources are yet to be tapped by our fishermen.

\section{Present fishing pattern and deep sea fishing in India}

As per Marine census carried out in 2010 by Govt. of India; altogether 52,982 Traditional crafts, 73,410 Motorized crafts and 72,749 Mechanized crafts are in operation along the coast of India which contributes to the total Marine landing of the country. Though the Marine census was carried out in the year 2016, the report is yet to be published.

The differences in resource abundance and composition of fishing fleet are also reflected in the fishing pattern in the country. In 2012, Kerala landed the largest volume of fish $(0.84$ million metric tonne or mt). All maritime States and Union Territories (UTs), except West Bengal and Odisha witnessed an increase in production during 2012 compared to the previous year. Comparing region-wise landings, SWAS region (Southwest Arabian Sea) comprising Kerala, Karnataka and Goa contributed maximum with $1.39 \mathrm{mt}$ (35.1\%) followed by NWAS region (Northwest Arabian Sea) which includes Gujarat, Maharashtra and UT of Daman and Diu with $1.15 \mathrm{mt}$ (29.2\%). On the east coast, the SEBOB region (Southeast Bay of Bengal) covering Andhra Pradesh, Tamil Nadu and UT of Pondicherry contributed $1.01 \mathrm{mt}(25.5 \%)$ while the NEBOB region (Northeast Bay of Bengal) comprising West Bengal and Odisha landed $0.4 \mathrm{mt}$ (10.2\%). The region-wise pattern of landings also favorably correlates with the potential identified for these regions. About 200 different types of species are harvested every year using more than 35 different types of craft-gear combinations. Mechanized trawl nets operated throughout the coast are by far the largest contributors with over 50 percent of landing. However, mechanized ring seines, popular along the Kerala coast, especially for oil sardine fishery, are the most efficient fishing gear with a catch per unit effort (CPUE) of $1264 \mathrm{~kg}$ per hour as compared to $48 \mathrm{~kg}$ per hour for trawl nets. Non-mechanized gear employed by the artisanal fishers on the other hand landed about 2.63 percent of the catch on an average during 2008-12.

\section{Fishing scenario in the EEZ and beyond (ABNJ)}

The deep sea fishing fleet in India can be broadly categorized under four heads. The first comprises fishing trawlers converted to tuna long liners under a scheme implemented by the MPEDA. The second category includes the vessels of 20 meter OAL and above brought through the Letter of Permission (LOPs) issued by the Department of Animal Husbandry, Dairying and Fisheries (DAHD\&F), Ministry of Agriculture. The deep sea going fishing vessels of Thoothoor in Kanyakumari district form the third category. These vessels also have a collective called the Association of Deep Sea Going Artisanal Fishermen (ADSGAF). The fourth category of vessels is from Visakhapatnam and they also fish in the deeper waters off the coast of Andhra Pradesh. These vessel apart from deeper waters of our EEZ also carry out fishing in the area beyond our national jurisdiction i.e. international waters.

\section{Toothoor fishing vessels}

The present size of the deep sea going fleet of Thoothoor is 588 (December 2012). These fishing vessels are mostly within the length of 12-14 meters and 16-18 meters, although some vessels are also in the length range of 18 -22 meters. They operate around Okha and Veraval in Gujarat; Mumbai and Ratnagiri in Maharashtra; Karwar and Mangalore in Karnataka; Cochin and Quilon in Kerala; and Kanyakumari in Tamil Nadu. Occasionally, some of them also fish in the Bay of Bengal. Besides, the Toothoor fishermen are also being engaged by boats of other States fishing in the deep sea. 


\section{Vast Research Linkages/ Governmental initiatives}

There exist a vast network of research organization like Fishery Survey of India (FSI), Ministry of Earth Sciences (MoES), Central Marine Fisheries Research Institute (CMFRI), Central Institute of Fisheries Technology (CIFT), Central Institute of Fisheries Nautical and Engineering Training (CIFNET), Central Institute of Coastal Engineering for Fisheries (CICEF) and State Universities which are engaged the deep sea fisheries research in India. ${ }^{4}$ In my view these are the premier institutions which are involved in deep sea research so there cannot be a second opinion about it. In the recent years, these research organizations had lauded the need of tapping the deep sea fishery resources.

Apart from the above under exploited resources, the following few more identified areas can be taken up for better earning from the exploited deep sea resources.

\section{Development of value added products}

To cop up with the demand of fish and present supply an immediate need of improving fish availability at a affordable price is the need of the hour. As the deep-sea fishes does not attract the high consumer preference due to its unfamiliar appearance, taste and texture, but there is a vast scope of research and development of value added products from these fishes for meeting the food security of the country. At this juncture, this resource can act as a buffer for the consumers by providing a cheap protein source. According to Viswanatha et al. ${ }^{26}$ the preferences of consumers are heterogeneous, but it is possible to identify the segments with distinct preferences for particular fish attributes; the price of the fish was found to be the most important attribute that explained consumers preference followed by fat content, texture and length of the fish. I too agree with the view that when there is a preference of taste, texture and preference with the challenging prices of coastal fishes the deep sea fishes can be an alternative to this attributes. The protein content of some of the myctophids are higher than the coastal fishes ${ }^{27,28}$ studied that the oils derived from Southern ocean myctophids have some industrial uses and have potential similar to that of jojoba oil.

\section{Constituent as pharmaceutical industries}

The deep-sea fish resources can also be used in the pharmaceutical industry as it has potential for manufacturing specialized products. For example, Squalene is pharmaceutical compounds extracted from shark liver and are being used for manufacturing Shark liver oil which is high in Vitamin- A content. Similarly the tuna eye and bones can be utilized as a source of calcium while manufacturing Sandoz (a calcium tablet).

\section{Input for the animal food and fish meal}

Fish meal is an important ingredient for manufacturing fish and shrimp feeds which is the back bone of aquaculture sector as the cost of feed alone is $60 \%$ of the operational cost in Shrimp aquaculture. As on today India still depends on the imported Fish meal because the high value coastal fishes cannot be spared for fish meal. Therefore, the exploited deep-sea fish resources could be utilized as animal food and fish meal. Similarly even the small unutilized trash deep sea fishes can be utilized to produce the cannibalistic fishes such as Sea bass and Catfishes which are being fed with raw Fish flesh.

\section{High prospects for Government support by way of different schemes}

Indian deep-sea fishing industry has not been fully developed whether it is technologically or financially, to take up this venture by our poor fishermen. Therefore, the Government of India has been taking several steps in the past to finance deep-sea fishing ventures and to bring in appropriate technologies. As a result of these efforts, several joint venture initiatives and Indian owned deep-sea fishing ventures have come up in recent days. However still the Govt. of India need to take little initiative so as to train our fishermen and demonstrate the technology in order to harvest the deep sea resources available within our EEZ and adjoining area beyond national jurisdiction. In this regard Govt. of India, with financial support from NFDB has already trained more than 180 fishermen in modern technology of Tuna log lining on board FSI survey vessels from three different states i.e. Tamil Nadu, Andhra Pradesh and Kerala. Similar efforts are expected from GOI to promote the deep sea fisheries.

\section{Issues}

The following are the issues which require immediate attention while conceiving the idea of developing the deep-sea fishery sector.

\section{i. Sound and Suitable Dee sea Fishing Policy}

The opportunity of fishable concentrations of deep-sea resources while coastal fish production is at stagnation, necessitated the need to recognize the deep-sea fishing as a priority area. Accordingly, Government has approved projects for investment and development of importing larger ocean going fishing vessels and joint venture and charter programs for increasing the marine fish production (Planning commission, 2011). In 1991, the Government formulated a deep-sea Fishing Policy in which the Indian seas were opened up to the foreign factory fishing ships under the guise of Joint Venture and Lease and test fishing besides allowing continuing the vessels chartered under 1986 Charter Policy till the validity of their permits lasted. From the beginning of 1994, the deep sea fishing policy was criticized by various fisher groups, mechanized fishing vessel owners, fish processors etc. (Comprehensive Marine Fishing Policy, 2004). ${ }^{29}$

As per the said policy the Deep sea Fishing Vessels (DSFV) were alleged to fish in near-shore waters, often within the territorial waters, causing much damage to the resources as also the livelihoods of small-scale fishermen. This resulted in the setting up of a Committee by the Ministry of Food Processing Industries (MFPI) in February 1995 under the chairmanship of Shri P Murari, former Secretary to the Government of India and was popularly referred to as "Murari Committee". The report recommended 21 points including cancellation of licenses of the chartered/joint venture fishing vessels. Based on the acceptance of the recommendations, the New Deep Sea Fishing Policy of 1991 was rescinded and no new permit, extension or renewal of the permits under the above policies was given. This decision of the Government also brought to an end the third phase of the country's attempt to exploit the deep sea fisheries resource through foreign fishing vessels and other similar arrangements. The major concern had been lack of a sound deep-sea fishing policy which needs orientation regarding operation of Indian vessels in the deep-sea fishing zone. Another constraint is regarding strengthening of the existing Indian fleet which has been a major obstacle in the development of this sector in our country. Therefore, the deep-sea fishing in India (which began in 1970s) had been merely confined to the upper east coast for shrimps and the same has also been dwindled in recent years. However, FSI survey and CMLRI (Sagar Sampada) Survey indicates that there is an ample amount of unexploited and non-conventional resources in the Indian EEZ.

In the next step of regulatory actions, the Government of India issued the first set of Guidelines on 01 November 2002. These guidelines, with the purport of ensuring proper conduct of the DSFVs 
in the Indian EEZ, qualified the resource-specific fishing methods ((i) long lining for tuna, (ii) tuna purse seining, (iii) squid jigging and squid hand lining, (iv) mid-water pelagic trawling, (v) trap fishing) that were allowed under the LOP, and also outlined 21 do's and don'ts for the proper conduct and smooth operation of such fishing vessels. The Guidelines also defined deep sea fishing (fishing activities beyond 12 nautical miles from the shore line i.e.the Territorial Waters) and deep sea fishing vessels (fishing vessels of 20 meter overall length and above).

Later, Government of India vide its order dated 06 September 2004 marginally amended the 2002 Guidelines by incorporating two additional resource-specific fishing methods, viz., (i) hook and line fishing and (ii) pole and line fishing.

However, keeping in mind the issues before the deep sea fishing sector and also the growing chasm between the small-scale and deep sea fishing operators, the Government set up a Committee to prepare a comprehensive policy for marine fisheries sector as a whole. Thus in October 2004 the Government released the long overdue first Comprehensive Marine Fishing Policy (CMFP, 2004). This policy, looking at the sector comprehensively, provided over-arching guidance for the development of the sector in the mainland as also in the two groups of Islands. The 2002 Guidelines (as amended in September 2004) were further amended in May 2006 by including monofilament long liners of 15- 20 meter OAL.

The contributions of the Comprehensive Marine Fishing Policy, 2004 in providing a framework and thereafter the guidelines for deep sea fishing in the Indian EEZ, has not been able to focus much on other aspects of the sector. It can also be said that after introduction of fishing vessels under the deferred payment provisions of the 2000 EXIM Policy of the Ministry of Commerce and Industry, the deep sea activities have received much focus, leaving coastal fisheries to its own fate. The policy also has other inherent weaknesses, such as the lack of an implementation plan, timelines and budgetary support to make things happen at the ground level.

Further, in December 2006, as a follow-up on implementation of the actions of the CMFP, 2004 and based on the recommendations of the Executive Committee (EC), the Government issued another Public Notice, whereby operation of DSVFs of 20 meter OAL and above were also permitted under Joint Venture. However, in this category only tuna long liners, squid jiggers, purse seiners and pole and line fishing vessels were permitted, which continued to be regulated by the total number of fishing vessels permitted under the Public Notice issued in May 2005.

Subsequently on 01 August 2013, the Government constituted an Expert Committee under the chairpersonship of the $\mathrm{Dr} B$ Meenakumari, Deputy Director General (Fisheries), Indian Council of Agricultural Research, New Delhi (Krishnakumar, 2014) ${ }^{30}$ The committee's report, was submitted in August, 2014 to the Department of Animal Husbandry, Dairying and Fisheries (DAHD\&F) of the Ministry of Agriculture and Farmers Welfare could not be approved by DAHD\&F due to country wide agitation by the fishermen's organizations against the recommendations.

According to Krishnakumar, $2014^{30}$ article in Frontline magazine ( 31 st Octoberr, 2014 issue), the committee has, said that production in India from the near-shore waters has plateaued and that there is very little scope for increasing production in waters up to a depth of 200 metres but waters beyond a depth of $500 \mathrm{~m}$ are not optimally exploited, and there is considerable scope of expansion in this zone, mainly for tuna and tuna-like species, which are in demand in the international market.
He stated in his article that, the most controversial recommendations was the creation of a buffer zone between the near-shore and offshore regions (waters between $200 \mathrm{~m}$ and $500 \mathrm{~m}$ in depth) along the coast and to regulate fishing there "in order to augment resources in the near-shore areas as well as the deep-sea regions in the EEZ". The committee said that exploitation of resources in waters between $200 \mathrm{~m}$ and $500 \mathrm{~m}$ "is now beginning, as small fishing boats [mainly measuring between $15 \mathrm{~m}$ and $20 \mathrm{~m}$ ] are targeting the resources in this area". The report recommended that "this depth zone may largely be kept as a buffer zone to augment the resources in both near-shore waters as well as offshore areas. Subsequently, this zone could also be utilised to diversify the existing fishing fleet for targeting resources such as squids and reducing pressure on near-shore waters in the future." (Krishnakumar, 2014). ${ }^{30}$

The second controversial recommendation of the report was to throw open off-shore regions for fishing by foreign and joint venture companies (a suggestion that was rejected by an expert committee in 1996) until the domestic fishers acquired the capability and techniques for effective deep-sea fishing. (Krishnakumar, 2014). ${ }^{30}$

The third contentious proposal was to allow tuna fishing by deep-sea vessels even during the period of uniform ban on fishing implemented by the Government of India every year "as this ban period does not coincide with the spawning seasons of tuna species such as yellow fin and big eye tuna", which are high-value products in the international market (Krishnakumar, 2014). ${ }^{30}$

The committee has said that "waters beyond 500-metre depth are not optimally exploited and there is considerable scope for expansion in this zone, mainly for tuna and tuna-like species". It has, therefore, recommended the introduction of "resource-specific fishing vessels" in this area.

"Based on the resource potential of tuna and tuna-like resources and other commercial species such as squids, the committee recommended a fleet size of 1,178 DSFVs [deep-sea fishing vessels] which needs to be considered for deployment in the Indian EEZ,". This figure of the fleet size was with the introduction of 270 vessels (240 tuna long liners, 15 purse seiners and 15 squid jiggers), in addition to the existing deep-sea vessels in the sector. This proposal indicated additional fleets in addition to the existing ones which was not at all acceptable to the majority of the population working in this sector.

According to the report, tuna and tuna-like resources in the Indian EEZ were valued at approximately Rs.3,000 Crore (\$500 million). The report suggested that "In the absence of the Indian fleet unable to harvest this resource, the migratory stocks of tuna and tuna-like species are being caught by the fishing fleet of the neighboring tuna fishing nations such as the Maldives, Sri Lanka, Thailand and Indonesia. This, in other words, could be termed as a net loss of revenue to the Indian fisheries sector."

In this context, the report said, "the industry has requested a review of this ban period for the DSFVs and suggested that such vessels may be exempted from the purview of the ban."

The recommendation of the committee on the statement "India does not have adequate expertise or resources to exploit waters beyond $500 \mathrm{~m}$ " and, therefore, may have to go in for "technology transfer through acquisition of foreign fishing vessels and, or, joint ventures/leasing" until domestic capacity is developed fully which was criticized critically by the stakeholders. The committee's report also said that "in view of the developments in exploitation of the resources in waters beyond 12 nautical miles, there was an urgent need to enact a comprehensive legislation for the regulation of the 
Indian fishing fleet in the EEZ, ; for which, may be the report was intended for

Due to severe criticism and agitation among the stake holders on the Dr. Meenakumari report, the Govt. of India constituted a committee on 28th July, 2015 under the chairmanship of Dr. S. Ayyappan, former Director General, Indian Council of Agricultural Research (ICAR) with terms of reference to inter alia ascertain the present status of exploitation of marine fishery resources by various sectors, namely, traditional sector, mechanized boats sector and deep sea fishing vessels; and to consult all stakeholders for preparing a draft National Policy on Marine Fisheries for over-all development of marine fisheries in India. Accordingly the committee after comprehensive stakeholder consultations submitted its final draft of National Policy on Marine Fisheries- 2016 on 01.09.2016 to Govt. of India. ${ }^{31}$ The draft was placed in the public domain by Govt. of India inviting comments, suggestions within Fifteen days. The committee made several recommendations to the Govt., among which few recommendation are highlighted below which are of great importance.

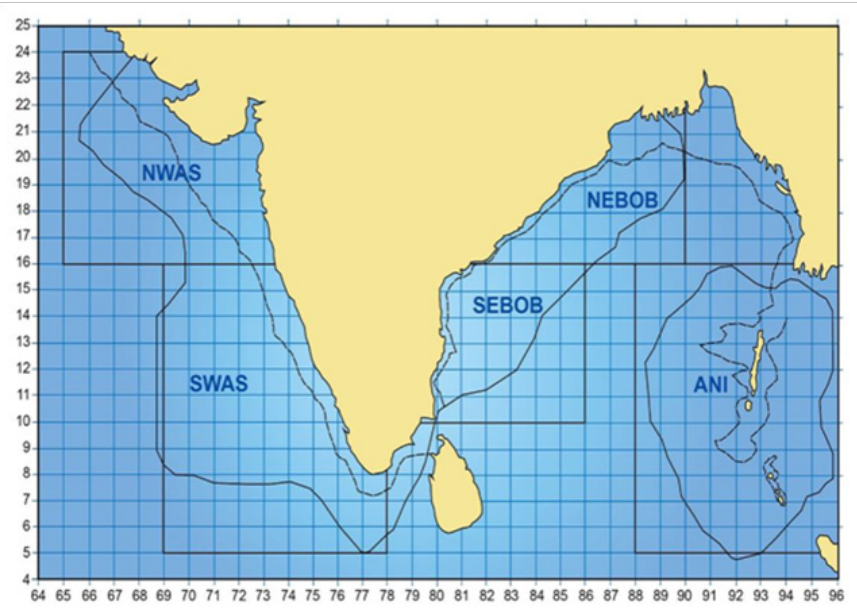

Figure I EEZ and Marine production zones of the Indian seas.

1. Fisheries sector plays an important role in trade and commerce, and in the process promotes employment and livelihoods of coastal communities.

2. The average marine fish catch during the last 4 years (2012-13 to 2015-16) is $3.499 \mathrm{mmt}$, whereas in $2015-16$ it was $3.583 \mathrm{mmt}$ (P). While the fisheries resources from the near-shore waters are fully utilized, the deep sea and oceanic waters offer opportunities of increasing the catch.

3. In terms of revenue, the high value species such as tunas that occur in the oceanic waters are yet to be optimally harvested. As the sector is quite dynamic, there is a need to streamline the policies and programmes to take advantage of the present sum of technical knowledge and the state of resources.

4. The average marine fish harvests from the seas around India are close to the current potential yield estimates, indicating optimum harvesting of the resources within the 200-meter depth. On the other hand, the oceanic waters still contain an untapped potential of high value resources like tuna, tuna-like species, myctophids and oceanic squids

5. To realize the full potential of marine fisheries, efforts should be towards fishing effort management; fleet-size optimization; mainstreaming biodiversity conservation in production processes; species-specific and area-specific management plans, including conservation of Ecologically and Biologically Significant Areas (EBSAs) and Vulnerable Marine Ecosystems (VMEs); protection of iconic and endangered and threatened (ETP) species; spatial and temporal measures for sustainable utilization of resources; and creation of fish refugia through consultative processes.

6. The Government should introduce new development scheme(s) for enhancing the skills and capabilities of the traditional fishermen to undertake deep sea fishing including modernization of existing indigenous deep sea fishing fleet, introduction of new indigenous deep sea fishing boats through fishermen cooperatives/self-help groups, on-board training and linkages to markets and export.

7. The deep sea resources should be harnessed after development of infrastructure, human capacity development and with a strong Monitoring, Control and Surveillance (MCS) regime, utilizing the available scientific and technical information's on the commercial fisheries resources.

8. There is a considerable scope to harvest the fishery resources of the high seas or in Areas Beyond National Jurisdiction (ABNJ) as done by many other countries.

The above details are available in the Dept. of Animal Husbandry, Dairying and Fisheries, MOA\&FW, Govt. of India website. ${ }^{31}$

In my view the above recommendations made by the committee is fishermen friendly and due care has been taken as the stake holders were consulted. It is expected that if the recommendations are approved by the Govt. and timely review is made as and when demanded based on the exigencies; the marine fisheries sector in India will become a sustainable and well-managed entity, ensuring food security and nutrition; generating employment, gender equity and enhanced livelihood security; addressing gender equity and equality; which will create wealth and prosperity in the sector.

Hence our Deep Sea Fishing Policy (DSFP) should be re-oriented to exploit the fishery resources beyond 100 metres depth giving thrust to indigenous technology and more employment generation for coastal fisher folks to avoid social conflicts.

\section{ii. Unorganized marketing system}

The existing marketing system in India does not have any forward or backward linkages. Moreover, there is a wide difference between fish sale price at landing centres and the retail markets which indicates that the middlemen is benefitted with the substantial share of the prices. Therefore, the Government should intervene and take appropriate measures so that the fishers get the due price of his product. Secondly most of the resources caught in the high seas are discarded out at sea except for high value resources like shrimps and sharks. Even shark flesh is discarded out at sea except the fins which has high export value. About $80 \%$ of the traders dealing with the deep sea fishes are facing a tough time due to competitive market. It also suggested that the harbor linked cooperatives marketing system needs to be introduced so that the stakeholders who all are involved get their due remunerations based on their efforts.

\section{iii. Strengthening of time series data on the deep sea the} resources

In recent years deep-sea resources are being well studied but there is a no time series data. Few institute like FSI and CMLRI which conducts survey do have scattered data which need to be made available to the public domain. However still there is a paucity of reliable data mainly on the stock assessment. Deep sea resources like tuna and allied resources are straddling stock so exact stock 
assessment of these resources is also difficult as per the managers and Scientists. . Moreover, the research on deep-sea resources done in Indian waters is confined to species specific or location specific which provides immense scope of collecting spatial and temporal data across Indian waters to analyze the diversity, abundance and availability of deep-sea resources for proper exploitation and management of these resources. However the time series data available with FSI on Tuna resources and deep sea shrimps can be utilized for further research.

\section{iv. Higher Capital Investment and Recurring cost}

The deep sea fishing needs higher capital investment and recurring cost. In general terms the deep-sea fishing is expensive compared to the coastal trawling operations. The higher cost of fishing coupled with scattered and straddling resources discourages the fishermen to go for this fishing. In this context Government must introduce new financial schemes directly or through NABARD so that more and more entrepreneurs come forward to undertake the challenges.

\section{v. Non availability of skilled manpower}

In India, when the deep sea fishing sector is not organized this is well known that there will be no or adequate manpower with technical competency. Almost all the deep sea boat owners who surveyed felt that the longer duration of fishing in this sector is a major limiting factor for non availability of Skilled man power. In recent past, the fishermen of Thoothoor-Colachel region are the major group engaged in deep-sea fishing activities mainly targeting sharks and large pelagic fishes like tunas and billfishes. The skills of this indigenous deepsea fishermen community can be tapped efficiently for developing the deep-sea fishery sector. Moreover FSI is also imparting on hand training to the fishermen in modern tuna long lining technology which can be explored. Till date FSI has trained more than 180 fishermen from various states. However it is essential that imparting further training and technical expertise will yield better catch rate and revenue.

\section{vi. Intrinsic life history traits of deep sea fishes}

Deep-sea fishes in general have longer life, slower growth, late maturity and less egg laying capacity. Moreover, large pelagics are migratory in nature and are not confined to one area. They are protuberance to Environmental fluctuations. Therefore, the deep-sea resources demands precautionary approach to ensure its sustainability before the resources is commercially exploited.

\section{Challenges}

To develop this sector the following challenges need to be addressed otherwise the sector will be nightmare.

\section{a. Dearth of investments}

The funding from the Government needs to be channelized considering the importance and scope of the deep-sea sector in the coming years. It is suggested that refinancing from NABARD can be arranged by the Govt. by issuing a notification or the subsidy schemes may be made available to the interested entrepreneurs by the Govt.

\section{b. Lack of awareness among the consumers and low market} acceptability

Deep sea fishes are of typical colors due to their habitat which makes them unpopular among the consumers due to lack of awareness. Moreover the Indian consumers are God believers and they have social stigma. It is worthy to mention here that only less than 40 per cent of the consumers are aware about the deep-sea resources including deep-sea shrimps. In India except Tamil Nadu and Kerala the deepsea fishes are not consumed and preferred. The exploitation of the deep-sea resources is in the back foot as it's market acceptability is a grappling problem. Very few markets and traders are marketing these resources due to low market acceptability. Many are of the view that there is no demand for the deep-sea resources due to their the appearance, texture and unfamiliar taste of the meat.

\section{c. Technology gap for exploitation}

The sound and handy fishing technology ensures sustainable and efficient exploitation of the resources. Moreover the identification of suitable and productive fishing ground is the need of the hour for better economic viable fishing. The technology includes catch limits determination, minimum discard oriented gears and suitable utilization and value addition.

\section{d. Lack of value addition technology}

Currently, National Institute of Post Harvest Technology and Training (NIPHATT) and Central Institute of Fisheries Technology (CIFT) in the Govt. sector has been working on the development of value added products from deep-sea non-conventional fisheries resources. However there is a huge gap in the technological expertise and further standardization of the developed technology by these institutes. Therefore, per-se the technologies need to be standardized at the earliest for ensuring that the value addition process is successful and more importantly suiting to the industry for commercial production at a minimum cost.

\section{e. National security}

After the Mumbai terror attack during 2008, the security concerns of the country have been a million dollar challenge to the security forces and the Union Govt. This issue needs adequate deliberation and it should be addressed while developing or inducting a deep-sea fishing fleet. The Vessel Monitoring System (VMS) developed by Space application Centre and thoroughly experimented by FSI can handy but the MCS system needs to be strengthened.

\section{f. Sustainability / Sectoral concerns}

It is necessary that the deep sea fishing vessel operating in high sea comply with the Conduct for Responsible Fisheries (CCRF) and other such national/ international obligations. More than that, the deep sea fishing should be ensured to have a conflict-free operation. More over the sectoral disputes raise a serious concern to the deep sea sector as the operation is intended to be a sustainable one.

\section{g. Policy bottlenecks}

As the development of a deep-sea fishing policy is a herculean task in front of the Govt. but it needs to be framed at the earliest taking into consideration the resource potential, available skilled manpower and prospects to earn better revenue and also create employment opportunities for the youths. The policy should not be a bottle neck for the sector otherwise the resources are going to be affected in many ways as it has been in the past.

\section{h. Infrastructure facility}

The infrastructure facility like Standard Boat building yards for construction of New boats and repair of existing crafts, exclusive fishing harbor, landing centre, processing plant, ice plant, drinking water bunkering facility, market place etc pose a huge challenge for this sector in fisheries. But it is not a nightmare for the Govt to set up the infrastructures as it is going to pay back with foreign exchange. 


\section{i. Compliance of International guidelines}

International guidelines and codes though are mostly voluntary and it is more of an instrument of reference to help the states in formulating and also implementing the appropriate measures for the management of deep-sea fisheries in the high seas. But the country has to abide the international obligations if they have to market their product in the international market and compete with the international standards. Therefore their adoption is a major step towards addressing both fisheries management and marine biodiversity conservation in an integrated manner. This also gives a way to develop and strengthen the applicable legal and institutional framework the world over Therefore, it becomes mandatory for the nation to comply these guidelines. ${ }^{32-40}$

\section{Conclusion}

Fishing rights and responsibilities it entails in the deep-sea sector has been a vexed issue since the mid-nineties and various stakeholders have different opinion on the modalities of harnessing the marine fisheries wealth, especially from the oceanic and deeper waters. ${ }^{4}$ While there is enormous potential for the exploitation of oceanic larger pelagic from the pelagic region of deeper wares and non-conventional resources from the mesopelagic realms of deeper waters, it is essential to develop value added products for domestic and export markets. It is also essential to create awareness on the edible qualities and the nutrient values of the non-conventional resources among the public through various print and electronic media so as to generate a free market for many such deep sea resources. Research and development programmes should be strengthened through projects on exploratory deep sea surveys for pelagic, meso-pelagic and bathypelagic resources and their tropic and population dynamics.

As described earlier in this paper, the exploitation and utilization of these resources pose a serious challenge as far as the technology development and up-gradation in harvest and post-harvest areas are concerned; besides development of infrastructure facilities such as berthing, handling, storing and processing). It is necessary to clearly define and delimit deep sea fishing areas to cover the region beyond the $150 \mathrm{~m}$ depth zone. It is further important that care should be taken that the deep sea commercial operation should in no way encroach upon or disturb the resource availability to the coastal sector. The Govt. should also take steps to ensure conservation of threatened and endangered deep sea resources such as shrimp and lobsters through legal provisions, more importantly the compliance and regular monitoring of legal provision should be ensured. At present, in India though the deep-sea fishes don't have ready market however creating awareness among consumers and converting into value added products is a way forward. Many problems have so far been confronted by the sector without allowing the sector to flourish and reach to its full potential. Therefore, there need to be a sound deep-sea fishing policy revolving round the up-gradation of the small scale fishermen of the country, who have the inherent skills but lack adequate support from the Govt. to develop and to acquire or convert the vessels having the capability to operate in high seas. To develop the sector and turn it around to sustainable fisheries on the basis of long lining operations is a herculean task in front of the Govt. Further to provide required training for up-gradation of the skills and capacity building of the fishermen is also another task need to be addressed. It is also important that the development agencies has to provide infrastructure facilities (shore cold storage facilities at identified ports, harbours, landing centers and fish auction halls) for the highest economic returns. There should be a mechanism for quick dissemination of the results of such scientific investigations in an understandable language to end users and entrepreneurs. Deep sea fishing is a multi-disciplinary subject and necessitates the input of several activities in an integrated manner for its development. Therefore the strategy for increasing production should be an integrated approach of exploiting and utilizing the offshore, oceanic and deep sea resources and promoting internal market and overseas trade. In my view the Government agencies should develop a grass root approach in terms of developing the sector. The deep-sea fishing sector at present is in its nascent stage and needs immediate attention of the Government so as to minimize the fishing pressure in the inshore waters and also to boost the marine fish production through exploitation of deeper waters thereby ensuring food and nutritional security at large.

The main objectives of the Deep sea policies should be to ensure sustainable development of marine fisheries with due concern for ecological integrity and biodiversity, registration of fishing vessels, observation of closed seasons, ban on operation of mechanized vessels in the inshore areas, elimination of destructive fishing practices, implementation of mesh size regulation, reduction of by catch and discards, establishing Marine Protected areas, and establishing an effective Monitoring, Control and Surveillance mechanism. The following the few suggestions are elaborated to the policy makers which needs to be addressed while deliberating the deep-sea fisheries policy issue.

- Ensure deep-sea tuna stocks are managed sustainably using best available scientific information's, matching with the desires of stakeholders.

- Improve the quality, hygiene and value of tuna and other deep sea products.

- Provide an enabling environment for better trade and marketing of products.

- Enhance the understanding of supply chain dynamics for reducing costs and deriving greater economic benefits.

- Establish regional cooperation in monitoring and managing the use of shared deep sea fish resources.

- Strengthen linkages and collaborative partnerships with the fishers, governments, industries and institutions to find solution to problems and to achieve the sector's goal.

- Develop cohesive regional/national image to improve public opinion on the importance of deep sea sector and enhance the reputation of the fishery as sustainable.

- To comply with the Code of Conduct for Responsible Fisheries (CCRF) and other international obligations in managing the fish stocks.

In general, fisheries generate significantly more value when they are sustainably managed, and also provide biological and social benefits. Furthermore, the economics of the global seafood market suggests that prices and demand for sustainable products will increase. Therefore, investing in sustainable fisheries can be seen as both a necessary and potentially profitable investment.There is a clear opportunity to build sustainable and profitable deep sea fisheries in the India for significant social, economic and biological benefits. The industry can develop projects that are designed to deliver sustainable, profitable fisheries and that can be financed using multiple sources of capital. 
To conclude it is suggested that Government of India should finalize the designed deep sea policy at the earliest and can start implementing policies and practices that enable these projects to move forward at a scale and pace that leads to economic, social and ecological security in the immediate future. The investors can also allocate capital towards the transition. To achieve this goal, a coordinated and a consorted approach between the public sector, the private sector and NGOs is required and each stakeholder has an opportunity to promote sustainable fisheries for a secured tomorrow.

\section{Acknowledgments}

None.

\section{Conflicts of interest}

None.

\section{References}

1. Planning Commission. Planning Commission (Govt. of India) Report of the working group on agriculture research and education for the eleventh five year plan. 2007;pp.458.

2. FAO. Deep-sea Fisheries in the High Seas- Ensuring sustainable use of marine. Resources and the protection of vulnerable marine ecosystems. Rome. 2009;pp.11.

3. Balchandran K, Gopinathan Menon N, Pillai NGK. Scope for exploitations and management of Non conventional fish resources of distant water of Indian EEZ. In: Proceeding of Fourth Indian Fisheries forum. 1999;405-409.

4. Hashim H, Pillai NGK. Disrtibution, diversity and biology of deep sea fishes in Indian EEZ. Ph.D Thesis submitted to CUSAT, Kochi. 2012;pp.131.

5. Mathew Sebastian. Deep sea fishing: Towards diversified operations. The Hindu 6th January, 2003.

6. Anrose A, Sinha MK Babu C. A Comparison of changes in the exploration and Exploitation Of Oceanic Tuna Resources in the Indian EEZ In. 2013;1970-2012.

7. Vijayakumaran K, Anrose A, Prabhakar Raj JE. Tuna resources, costs and earnings from tuna longliners . Bull Fish Sur India. 1992;24:61-78.

8. Suda A. Recent status of resources of tuna exploited by long line fishing in the Indian Ocean. Bull Far Seas Fish Res Lab. 1974;10:29-64.

9. Silas EG, Pillai PP. Tuna resources of the Indian seas-an overview. Proc Symp. Harvest and post-harvest Techn Fish. Fish Techol. 1985;20-27.

10. Dwivedi SN, Devaraj M. Tuna fisheries of the Indian Ocean and development prospects in Indian EEZ. Tuna Update. 1983;6-11.

11. Joseph KM. Some observations on the exploitation of the Indian Ocean tuna resources. Sea Food Export Journal. 1972;4(8):11-18.

12. Silas EG, Pillai PP. Tuna Fisheries in India. Recent trends in Marine. Fish Information Service T\&E Ser. 1979;13:1-10.

13. Haruta E. Long line fishing. Industrial Fisheries Association Annual, Cochin. 1983;31-38.

14. Sivasubramaniam K. The Tuna fishery in the EEZ's of the India Maldives and Srilanka. 1985.

15. Eapen PK. Tuna longline operation in west coast. Indian Sea Foods, II. 1964;(I)13-19.

16. Varghese KK, John ME, Sivaji V. Some observations on the tuna resources of Indian OceanBull. Fish Sur India. 1984;13:30-33.
17. Sulochanan P, John ME, Nair KNV. Preliminary observations on tuna resources of the Arabian Sea with particular reference to distribution pattern of Yellowfin tuna, Thunnus albacares (Bonnaterre). Bull Fish Surv India. 1986;14:21-23.

18. Sivaprakasam TE, Patil SM. Results of exploratory tuna-long line survey conducted in the Arabian Sea off South West Coast of India during 1985-86 Bull Fish Sur India. 1987;17:22-46.

19. Anrose A, Sinha MK, Kar AB , et al. Diversity and Potential of oceanic fishery resources in Andaman and Nicobar Islands. In Recent trends in Biodiversity of Andaman and Nicobar Islands. 2010:367-371.

20. Sudarsan D, Sivaprakasam TE, Somvanshi VS, et al. Assessment of oceanic tuna and allied fish resources of the Indian Exclusive Economic Zone based on exploratory surveys. Proc Nat Conf on Tunas. 1993;2122.

21. John ME and Somvanshi VS. Atlas of tunas, billfishes and sharks in the Indian EEZ around Andaman and Nicobar Islands. FSI. 2000;pp.25.

22. Somvanshi VS, Varghese S, Sivaraj P. Trends in the abundance indices of Yellowfin and Skipjack tunas in the Indian EEZ.IOTC Proceedings no. 2003;6:194-201.

23. John ME, Bhargava AK, Varghese S, et al. Fishery resources of the Indian EEZ around Andaman and Nicobar Islands. Bull Fish Survey India. 2005;28:1-38.

24. Somvanshi VS, Varghese S, Varghese SP. Introduction of monofilament long-line technology for harvesting oceanic tuna and allied resources in the Indian EEZ. Bull Fish Survey India. 2008;30:1-36.

25. Ayyappan S, ICAR. Handbook of Fisheries and Aquaculture. 2011;pp.1116.

26. Viswanatha BS, Reddy RM, Reddy BVC. Evaluation of consumer preferences for myctophids using conjoint analysis. Book of Abstracts. 9th Indian Fisheries Forum. 2012;pp.304.

27. Manju S, Chakraborty K, Bineesh KK, et al. Proximate composition and fatty acid profile of myctophid Diaphus watasei Jordan \& Starks, 1904 from the Arabian Sea. Indian J Fish. 2011;58(1):103-107.

28. Nicholas PD, Nicholas DS, Bakes MJ. Marine oil products in Australia. Inform. 1994;5:254-261.

29. Comprehensive Marine Fishing Policy. Comprehensive Marine Fishing Policy. (November 2004) Government of India Ministry of Agriculture, Department of Animal Husbandry \& Dairying, New Delhi. 15.

30. Krishnakumar R. Deep distrust. Article published in "The Frontline" magazine on 31st October, 2014.

31. Anon. Report of the committee for drafting the "National Policy on Marine Fisheries, submitted to Govt of India. 2016;pp.13.

32. Anon. Hand book on Fisheries Statistics. Dept of Animal Husbandry, Dairying and Fisheries, Ministry of Agriculture, Govt. of India 166. 2014 .

33. Anon. Report of the working group for revalidating the potential of fishery resources in the Indian EEZ pp 69. 2011

34. CMFRI. Annual Report 2010-11. Central Marine Fisheries Research Institute, Cochin 163. 2011.

35. Bensch AM, Gianni D, Gréboval S, et al. Worldwide review of bottom fisheries in the high seas. FAO Fisheries and Aquaculture Tech Paper 522, Rome, pp.145. 2009.

36. FAO. Report to the Govt. of India on exploratory tuna long lining fishing off South West Coast of India. Report FAO/UNDP (TA). 1967;2274:146. 
37. FAO. Report to the Govt. of India on tuna long lining development in India Based on the 1972 work of Chi-Yun Pao, FAO/TA Master Fisherman Report FAO/UNDP (TA). 1972;3074:1-8.

38. John ME, Patil SM, Somvanshi VS. Tuna resources off the east coast of India as revealed by charter operation. Bull Fish Sur India. 1988;17:2246.
39. John ME, Varghese S, Somvanshi VS. Preliminary observations in comparison of CPUE indices obtained in conventional and monofilament long lining. 2006.

40. Sivasubramaniyam K. The tuna fishery in EEZs of India, Maldives and Srilanka. BOBP/WP/. 1985;31:19-71. 